\title{
Sayısal ve Sözel Bölümlerdeki Üniversite Öğrencilerinin Sözcük Çözümleme Stratejilerinin İncelenmesi
}

\author{
Hazal ARTUVAN KORKMAZ \\ Ankara Üniversitesi, Tıp Fakültesi, Fizyoloji Anabilim Dalı, Ankara \\ hzlartuvan@gmail.com \\ ORCID ID: https://orcid.org/0000-0001-7739-8676 \\ Birkan GÜLDENOĞLU \\ Ankara Üniversitesi, Eğitim Bilimleri Fakültesi, Özel Eğitim Bölümü, Ankara \\ birkanguldenoglu@yahoo.com \\ ORCID ID: https://orcid.org/0000-0002-9629-1505 \\ Canan KALAYCIOĞLU \\ Ankara Üniversitesi, Tıp Fakültesi, Fizyoloji Anabilim Dalı, Ankara \\ cananelvanlioglu@gmail.com \\ ORCID ID: https://orcid.org/0000-0001-5203-1712
}

Araștırma Makalesi

DOI: $10.31592 /$ aeusbed.589093

Geliş Tarihi: 08.07.2019

Revize Tarihi: 05.08.2019

Kabul Tarihi: 17.09 .2019

\section{Atıf Bilgisi}

Artuvan Korkmaz, H., Güldenoğlu, B. ve Kalaycığlu, C. (2019). Sayısal ve sözel bölümlerdeki üniversite öğrencilerinin sözcük çözümleme stratejilerinin incelenmesi. Ahi Evran Üniversitesi Sosyal Bilimler Enstitüsü Dergisi, 5(2), 266-283.

\section{$\ddot{\mathbf{O Z}}$}

Bu araștırma, sayısal ve sözel bölümlerdeki üniversite öğrencilerinin temel aldıkları sözcük çözümleme stratejilerini karşılaştırmalı olarak incelemeyi amaçlayan betimsel bir çalışmadır. Araştırmaya, toplam 271 (135’i sayısal; 136'sı sözel bölümden olmak üzere) üniversite öğrencisi dahil edilmiş ve öğrencilerin sözcük çözümleme becerileri, anlamlı sözcüklerin çözümlenmesi ve anlamsız sözcüklerin çözümlenmesi olmak üzere iki farklı işlem ile değerlendirilmiștir. Bu aşamada anlamlı sözcük çiftleri ve anlamlı sözcüklerden olușturulan anlamsız sözcük çiftleri kullanılmıştır. Öğrenciler sözcükleri bir bilgisayar programı üzerinden sessizce okuyarak sözcük çiftlerinin aynı olup olmadığına karar vermişlerdir. Verdikleri yanıtlar bilgisayar programı tarafından doğruluk ve hız açısından kaydedilmiștir. Veriler, varyans analizi (GLM-ANOVA) ve iki faktörlï MANOVA (GLM-MANOVA) testleri kullanılarak analiz edilmiştir. Sonuçlar, her iki grupta yer alan öğrencilerin anlamlı sözcükleri anlamsız sözcüklere göre daha hızlı çözümlediklerini göstermiștir. Sözcük çözümleme performansı bakımından sayısal ve sözel bölümden gelen öğrenciler arasında anlamlı bir fark bulunmamıştır. Araştırmanın tartışma bölümünde, alanyazındaki tek ve çift yönlü okuma kuramları temelinde, analizlerden elde edilen bulgular ile öğrencilerin sözcük çözümleme stratejileri ayrıntılı olarak tartışılmıştır. Bu bulgular, sayısal ve sözel bölüm öğrencilerinin sözcük çözümleme sürecinde benzer sözcük çözümleme stratejileri kullandığını düşündürmektedir.

Anahtar Kelimeler: Çift yönlü okuma kuramı, sözcük çözümleme, üniversite öğrencileri, sesbilgisel çözümleme.

\section{Investigation of Word Decoding Strategies of University Students From Quantitative and Verbal Graduate Programs}

\section{ABSTRACT}

This is a descriptive study aiming to examine the main word decoding strategies of university students from quantitative and verbal graduate programs. A total of 271 (135 quantitative; 136 verbal) university students were enrolled in the current study and the word decoding skills were evaluated with two different processes that include decoding of real- words and decoding of pseudo-words. In this stage, real- word pairs and pseudo- word pairs formed from real- words were used. The students read the words silently through a computer program and decided whether the word pairs were the same. Their responses were recorded by the computer program for accuracy and speed. Data were analyzed by using variance analysis (GLM-ANOVA) and two-factor MANOVA (GLM-MANOVA) tests. The results showed that students in both groups decoded the real- words faster than the pseudo-words. There was no significant difference between the two groups in terms of their word decoding performance. In the conclusion part of the study, the findings obtained from the analyzes and the word decoding strategies of the students were discussed in detail based on the one-route and dual route-cascaded reading model in the literature. These results suggest that university students from quantitative and verbal programs have similar word decoding strategies.

Keywords: Dual route-cascaded reading model, phonological decoding, university students, word decoding. 


\section{Giriş}

Okuma, görsel, dilsel ve bilişsel işlevlerin uyumlu çalışmasıyla gerçekleştirilen, yazılı sembollerden anlama ulaşma sürecidir (Gough ve Tunmer, 1986; Tunmer, 2008). Yazılı harf/sembol tanıma basamağından sözcüğün anlamına erişimi ve sonrasında da sözdizimsel analizle bu sözcüklerden oluşan cümle ve metinlerin verdiği mesaja ulaşmayı hedefler (Güldenoğlu, Kargın ve Miller, 2014). Tam anlamıyla okumanın başarılı sayılabilmesi için okuyucunun çözümlediği sembollerin kendisi için bir anlam ifade etmesi beklenir (Güzel, 1998). Dolayısıyla okuma, sözcük çözümleme/kodlama ve anlama olmak üzere başlıca iki aşamanın başarılı bir şekilde gerçekleştirilmesini gerektirir. Sözcük çözümleme, yazılı harfleri çözümleme ve ses karşıllı̆̆na çevirebilme yeteneği, anlama ise çözümlenen sözcüklere ve sembollere anlam yükleme olarak tanımlanmaktadır (Hoover ve Gough, 1990; Lewis ve Doorlag, 1983; Ross, 1976).

Okuma sürecinin nasıl gerçekleştiğine dair iki temel kuram geliştirilmiştir. Bunlardan ilki sesbilgisel okuma kuramı olarak da adlandırılan tek yönlü okuma kuramıdır. Bu kurama göre okuma, sesbilgisel çözümlemeler yoluyla gerçekleşir. Okuyucular önce sözcükleri oluşturan sesbilgisel yapı bloklarını çözümler. Daha sonra çözümledikleri yapıları birleştirerek sözcükleri algılar ve algıladıkları sözcüklerle bu sözcüklerden oluşan cümle ve metinleri anlamlandırarak okumayı gerçekleştirirler (Frost, 1998; Frost, 2006; Ramus, Pidgeon ve Frith, 2003). Konu ile ilgili araştırmalarda, erken dönemde edinilen sesbilgisel bilgi ve beceriler ile ileride edinilmesi beklenen akıcı okuma becerileri arasında güçlü bir ilişki vardır (Ehri, 2002; Perfetti, 1985; Samuels ve Farstrup, 2006). Bu okuma kuramına göre, sesbilgisel bilgi ve becerilerdeki sınırlılık (alfabetik çözümlemedeki sınırlılık gibi) okuyucuların okuma performanslarını olumsuz etkilemektedir.

Jackson ve Coltheart (2001) tarafindan geliştirilen diğer okuma kuramı çift yönlü okuma kuramıdır (Dual-cascaded reading route). Buna göre okuyucular, okuma eylemi sirasında iki yol/strateji kullanmaktadırlar. Bunlardan ilki sözcük dağarcığına dayalı olmayan yol (nonlexical reading route) olarak adlandırılır. Okuyucuların yazılı sözcüklerdeki harfleri seslere dönüştürerek sesbilgisel çözümleme yaptıkları yol şeklinde tanımlanır. Okuma sırasında ortografinin kullanıldığı ikinci yol ise sözcük dağarcığına dayalı yol (lexical reading route) olarak adlandırılmaktadır. Burada, sözcükteki harf birimleri zihinde canlandırılarak, sözcük tanınıp anlamlandırılır. Çift yönlü okuma kuramına göre okuyucular, yeni bir sözcük ile karşılaştıklarında sesbilgisel çözümleme yaparlar. Daha sonraki karşılaşmalarda artık sözcügün bellekte karşılığı olduğundan, sesbilgisel çözümleme yerine ortografik olarak sözcüğü kodlar ve anlamlandırırlar. Bu kuramda okuyucuların okuma becerisinde ustalaştıkça, ortografik çözümleme yolunu daha fazla kullandıkları ifade edilmektedir (Jackson ve Coltheart, 2001). Bu yolu kullanan okuyucularda sözcüklerin ortografik çözümlenmesi daha hızlı olacağından okumanın hızlanacağı, böylece sesbilgisel çözümlemeye harcanan zamanın anlamlandırma için kullanılacağı söylenmektedir. Sonuç olarak, okuduğunu anlama performansının olumlu yönde etkileneceği ileri sürülmektedir (Paap ve Noel, 1991; Therrien, 2004). Okuma sirasında her iki yolu (lexical-nonlexical route) birlikte kullanan okuyucuların ise hem akıcılık hem de anlama performanslarında artış olması beklen-mektedir (Jackson ve Coltheart, 2001).

Okumanın en önemli amacının anlama olduğu düşünüldüğünde, okuyucuların bu amaca ulaşabilmeleri için öncelikle yazılı metinlerdeki sözcükleri doğru bir şekilde çözümlemeleri, ardından da çözümledikleri sözcükleri uygun şekillerde anlamlandırmaları gerekmektedir. Her ne kadar başarılı bir okuma performansı için tek başına yeterli olmasa da, alanyazında sözcük çözümleme becerisinin okuduğunu anlamanın önemli yordayıcılarından ve okuma sürecinde anlama boyutuna geçilebilmesi için kazanılması gereken temel önkoşul becerilerden biri olduğu belirtilmektedir (Güldenoğlu vd. 2014; Güldenoğlu, 2016; Hoover ve Gough, 1990). Eğitim-öğretimde, yeterli mesleki bilginin kazanılmasında ve profesyonel iş hayatında okuma becerilerinin önemi büyüktür. Üniversite eğitimi, terimler gibi ilk defa karşılaşılan veya günlük yazı dilinde kullanılma sıklığı az olan sözcüklerin yoğun olarak kullanıldığı bir dönemdir. Okuyucular ilk kez karşılaştıkları veya yazılı dilde kullanılma sıklığı az olan sözcükleri ayırt etmede sesbilgisel çözümlemeyi kullanmakta, bu sözcüklerde fazla zaman harcamaktadırlar. $\mathrm{Bu}$ durum akıcı okumanın aksamasına yol açmaktadır. Okuma performansı açısından böyle bir zayıflığa sahip olan öğrencilerin ders kitaplarından okuduklarını anlamaları ve 
başarılı olmaları beklenemez, ayrıca derse ilgileri azalır ve dikkati yönlendirmede problem yaşarlar (Güzel, 1998).

Akıcı okuma, sözcüklerin hızlı ve doğru olarak otomatik bir şekilde çözümlenmesini gerektirir. Bu da, okumanın öğrenilmesinden sonra bolca pratik yapılması ve sözcüklere ortografik olarak tanıdıklık geliştirilmesine bağlıdır. Okuma hızının, okuma deneyimi ve yaşa bağlı olarak özellikle 3.,4. ve 5. sinıflarda giderek arttı̆g 1 gözlenmiştir (Erden, Kurdoğlu ve Uslu, 2002). Miller (2005a), ilköğretim 5. sınıf ve üniversite öğrencilerini karşılaştırdığı çalışmasında, 5. sınıfta yazılı metinleri tanımada belirgin bir gelişkinlik düzeyine ulaşıldığını bildirmiştir. Araştırmacıya göre bu gelişkinlik, dikkati yönlendirme, yeni okuma stratejileri geliştirme, sözcük dağarcığında zenginleşmeyle ortografik yolun daha fazla kullanılması gibi bilişsel süreçler sayesinde elde edilmektedir. Araştırmacı, üniversite çağına gelindiğinde anlamlı veya anlamsız sözcük çözümleme hızında ve doğruluğunda ek bir gelişme olmadığını göstermiştir (Miller, 2005a).

Ülkemizde öğrenciler lise çağına geldiklerinde becerilerine ve yatkınlıklarına göre sayısal veya sözel alan tercihi yapmaktadır ve ağırlıklı olarak seçtikleri alana ait dersleri almaktadır. Üniversite eğitimlerine başlamadan önce tüm öğrenciler merkezi bir sınava tabi tutulmaktadır. Merkezi sinavda değerlendirilmeleri, okumak istedikleri üniversite bölümünün puan türüne göre değişmektedir. Başarı puanları hesaplanırken, sayısal ve sözel ders gruplarındaki netleri branşlara göre farklı katsayılarla çarpılmakta ve buna lisedeki okul başarı puanları eklenmektedir [Ölçme, Seçme ve Yerleştirme Merkezi (ÖSYM) Yükseköğretim Kurumları Sınavı (YKS) Kılavuzu, 2018]. Bu şekilde hesaplanan puanlara göre okul ve bölüm tercihi yaparak bölümlere yerleşmektedirler. Öğrencilerin daha başarılı oldukları alanlardaki bölümleri tercih etmeleri beklenir. Örneğin, sözel becerileri daha iyi olan bir öğrenci edebiyat, dilbilim, tarih, psikoloji gibi sözel yatkınlık gerektiren bölümleri; sayısal becerileri daha iyi olan öğrencilerse matematik, mühendislik gibi bölümleri seçmeye eğilimli olacaktır. Benzer şekilde sözel yatkınlığı olan öğrencilerin hem bireysel ilgilerinden hem de bulundukları alana ait derslerin fazlaca okuma yapmayı gerektirmesinden dolayı ortografik yolla okunan sözcük dağarcıklarının daha fazla gelişmesi ve daha akıcı okuması beklenir. Tüm bunlar birlikte düşünülecek olursa, sözel bölümleri tercih etmiş olan üniversite öğrencilerinin sesbilgisel ve/veya ortografik yolla sözcük çözümleme becerilerinde sayısal bölüm öğrencilerine göre farklılaşma olacağı öngörülebilir. Okuma becerileri sıklıkla ilkokul öğrencilerinde araştırılmış ve üniversite öğrenimi almaya gelmiş bireylerde bulunan farklılıklar üzerinde durulmamıştır. Oysaki üniversite eğitiminde öğrenciler derslerde ve kitaplarda çözümlenmesi zor olan birçok yeni terimle karşılaşırlar. Bunların hızlıca çözümlenmesi ders başarısını ve öğrencinin derse ilgisinin devam etmesini sağlayacaktır. Dolayısıyla sayısal veya sözel bölümden geliyor olmanın sözcük çözümleme üzerine olası bir etkisinin varlığı akademik başarıda önemli olacaktır. Bu görüşten hareketle kurgulanan bu çalışma, farklı okuma profiline sahip olan okuyucuların sözcük çözümleme sırasındaki beyin dalgalarının incelenmesine yönelik tıp alanında yapılan bir uzmanlık tezinin ilk aşamasından türetilmiştir.

Bu çalışmada sayısal ve sözel bölümlerde okuyan üniversite öğrencilerinin sözcük çözümleme sırasında temel aldıkları sözcük çözümleme stratejilerinin karşılaştırmalı olarak incelenmesi amaçlanmıştır. Çalışma içerisinde anlamlı ve anlamsız sözcük çözümleme hızı ve doğruluğunu değerlendiren bir tarama testi, sayısal ve sözel bölümlerde okuyan üniversite öğrencilerine bireysel olarak uygulanmıştır.

Belirtilen genel amaca yönelik olarak araştırma içerisinde test edilen araştırma hipotezleri aşağıda sunulmuştur;

a) Çalışmaya katılan tüm öğrenciler bir grup olarak düşünüldügünde, öğrenciler anlamlı sözcükleri anlamsız sözcüklere göre hem daha hızlı hem de daha doğru çözümleyeceklerdir.

b) Sözel bölümlerde öğrenim gören üniversite öğrencileri sayısal bölümlerdekilere göre her iki kategoride yer alan sözcükleri hem daha hızlı hem de daha doğru çözümleyeceklerdir.

c) Anlamlı ve anlamsız sözcükler arasındaki çözümleme hız ve doğruluk oranı farkları, sayısal bölümlerde öğrenim gören üniversite öğrencilerinde sözel bölüm öğrencilerine göre daha yüksek olacaktır. 


\section{Yöntem}

\section{Araștırma Modeli}

Bu çalışma sayısal ve sözel bölümlerde okuyan üniversite öğrencilerinin sözcük çözümleme sırasında temel aldıkları sözcük çözümleme stratejilerinin karşılaştırmalı olarak incelenmesini amaçlayan betimsel bir araştırmadır. Üniversite öğrencilerinin sayısal veya sözel bölümden gelen öğrenciler olmasının sözcük çözümleme stratejilerine etkisi ilişkisel tarama modeline göre karşılaştırılmıştır (Karasar, 2005).

\section{Evren ve Örneklem}

Araştırmaya Ankara'daki üniversitelerde halen öğrenim gören ve çalışmaya gönüllü olarak katılmayı kabul eden toplam 271 (135'i sayısal; 136'sı sözel bölümden) üniversite öğrencisi alınmıştır. Çalışma grubundaki öğrencilerin tamamı anadili Türkçe olan 18-25 yaş arası bireylerdir. Öğrenciler okuma bozukluğu ve özgül öğrenme güçlüğü tanısı almamış, çocuklukta veya halen tanısı konmuş nörolojik veya psikiyatrik hastalık öyküsü olmayan ve merkezi sinir sistemine etkili herhangi bir ilaç kullanmayan sağl1klı gönüllülerdir. Çalışmaya katılan öğrencilerin yaş, cinsiyet ve okumakta olduğu bölümlere göre dağılımları Tablo 1 ve 2'de sunulmuştur.

Tablo 1

Sayısal ve Sözel Gruplardaki Katılımcıların Yaş Ortalamast ve Cinsiyete Göre Dağıllımları

\begin{tabular}{lccc}
\hline & Yaş Ortalaması & \multicolumn{2}{c}{ Cinsiyet } \\
\cline { 3 - 4 }$(\mathrm{y} 1 \pm$ standart sapma $)$ & Kadın $(\%)$ & Erkek $(\%)$ \\
\hline Sayısal & $19,64 \pm 1,6$ & $65(\% 48,1)$ & $70(\% 51,9)$ \\
Sözel & $19,85 \pm 1,86$ & $93(\% 68,4)$ & $43(\% 31,6)$ \\
Toplam & $19,75 \pm 1,73$ & $158(\% 58,3)$ & $113(\% 41,7)$ \\
\hline
\end{tabular}

Tablo 1'de görüldüğü üzere öğrencilerin 158'i kadın, 113'ü erkek olup grubun yaș ortalamas1 19,75’tir. 135 sayısal bölüm öğrencisinin olduğu grupta 65 kadın, 70 erkek katılımc1; 136 sözel bölüm öğrencisinin bulunduğu grupta 93 kadın, 43 erkek öğrenci vardır.

Tablo 2

Sayısal ve Sözel Gruplardaki Katılımcıların Okumakta Olduğu Bölümlere Göre Kişi Sayısı ve Yüzdeleri

\begin{tabular}{lrrr}
\hline Sayısal Puan Türünden Gelen Katılımcılar & & & \\
\hline Bölüm & Frekans & Yüzde & Eğitim Durumu \\
\hline Alternatif Enerji Kaynakları Teknolojisi & 26 & 9,5 & Önlisans \\
Beslenme ve Diyetetik & 10 & 3,6 & Lisans \\
Biyoloji & 2 & 0,7 & Lisans \\
Biyomedikal Cihaz Teknolojisi & 20 & 7,3 & Önlisans \\
Ebelik & 13 & 4,8 & Lisans \\
Genetik & 3 & 1,1 & Lisans \\
Hemşirelik & 2 & 0,7 & Lisans \\
İşletme & 1 & 0,3 & Lisans \\
Jeoloji & 1 & 0,3 & Lisans \\
Kimya & 3 & 1,1 & Lisans \\
Mimarlik & 1 & 0,3 & Lisans \\
Mühendislik & 17 & 6,2 & Lisans \\
Odyoloji & 1 & 0,3 & Lisans \\
Tip & 35 & 12,9 & Lisans \\
\hline Toplam & 135 & 49,1 & \\
\hline
\end{tabular}




\begin{tabular}{lrrr}
\hline Sözel Puan Türü Türünden Gelen Katılımcılar & & & \\
\hline Bölüm & Frekans & Yüzde (\%) & Eğitim durumu \\
\hline Alman Dili ve Edebiyatı & 1 & 0,3 & Lisans \\
Antropoloji & 8 & 3,2 & Lisans \\
Dilbilim & 26 & 9,9 & Lisans \\
Fars Dili ve Edebiyatı & 2 & 0,7 & Lisans \\
Felsefe & 1 & 0,3 & Lisans \\
Gastronomi & 5 & 2,3 & Önlisans \\
Hungaroloji & 2 & 0,7 & Lisans \\
İlahiyat & 1 & 0,3 & Lisans \\
Japon Dili ve Edebiyatı & 1 & 0,3 & Lisans \\
Psikoloji & 56 & 20,7 & Lisans \\
Rehberlik ve Psikolojik Danışmanlık & 16 & 6 & Lisans \\
Resim Öğretmenliği & 1 & 0,3 & Lisans \\
Rus Dili ve Edebiyatı & 2 & 0,7 & Lisans \\
Sosyoloji & 1 & 0,3 & Lisans \\
Tarih & 2 & 0,7 & Lisans \\
Turizm ve Otel İșletmeciliği & 8 & 3,2 & Önlisans \\
Türk Dili ve Edebiyatı & 2 & 0,7 & Lisans \\
Uluslararası Ticaret & 1 & 0,3 & Lisans \\
\hline Toplam & 136 & 50,9 & \\
\hline Genel Toplam & 271 & 100 & \\
\hline
\end{tabular}

Tablo 2'de görüldüğü üzere en yüksek katılım Psikoloji bölümü öğrencilerinden olmuştur. Çalışmanın veri toplama aşamasında seçkisiz olarak tüm bölümlere aynı şartlarda duyuru yapılmış ve katılım tamamen gönüllülük esasına dayalı tutulmuştur. Bazı sınıflarda ilgi çok daha yüksekken bazı sınıflarda katılım birkaç kişi ile sınırlı kalmıştır. Tüm gönüllü öğrenciler çalışmaya alınmış, "sayısal ve sözel bölüm öğrencisi” şeklindeki gruplandırma daha sonra yapılmıştır. Çalışmaya katılan öğrenciler arasından katılımcı gruplarının belirlenmesi sırasında dikkate alınan temel ölçüt, öğrencilerin öğrenim gördükleri bölümlerin puan türüdür. Böylelikle her ne kadar farklı fakülte/yüksekokullardan olsalar da bölümlerin temel aldığı puan türüne göre çalışma içerisinde ele alınan sözel ve sayısal öğrenci grupları oluşturulabilmiştir. Bölümlere göre sınıflama Yükseköğretim Kurulu'nun yayınlamış olduğu "Yükseköğretim kurumları sınavı lisans programları-puan türleri tablosu" (YÖK, 2018) ile belirlenmiştir. Bu tabloya göre farklı puan türü (eşit ağırlık/dil puan türü) ile öğrenci kabul etmesine rağmen, gruplardaki katılımcı sayılarının yakın tutulabilmesi amacıyla bazı öğrenciler (dilbilim, psikoloji, sosyoloji gibi) sözel bölüm öğrencisi olarak kabul edilmiştir.

\section{Veri Toplama Araçları}

$\mathrm{Bu}$ çalışmada veri toplamak amacıyla bir bilgi formu, el tercihi anketi ve iki sözcük okuma işlemi kullanılmıştır. Aşağıda çalışma içerisinde kullanılan veri toplama araçlarına ilişkin ayrıntılı bilgiler sunulmuştur.

Bilgi Formu: Demografik özellikler ve genel sağlık durumları hakkında sorular içermektedir. Konuşma veya okuma bozukluğu/gecikmesi yaşayıp yaşamadıkları sorulmuştur. Ayrıca, yaşamlarının bir döneminde nörolojik veya psikiyatrik bir hastalık geçirip geçirmedikleri ve şu anda ilaç kullanıp kullanmadıkları kendilerinden öğrenilmiştir.

El Tercihi Anketi: Türkçeye çevrimi ve geçerlik güvenirlik çalışması tamamlanmış Chapman'ın 13 soruluk el tercihi anketi kullanılmıştır (Chapman ve Chapman, 1987; Nalçacı, Kalaycıoğlu, Güneş ve Çiçek, 2002). Bu ankette katılımcıların 13 farklı eylemi yaparken (Örneğin; yazı yazarken, diş firçalarken, bir şey fırlatırken...) öncelikli olarak hangi elini kullandıklarını düşünmeleri ve sağ/sol/her ikisini de yanıtlarından kendine en uygun olanı seçerek işaretlemeleri istenmiştir. Katılımcılar, sağ el cevabı için 1 puan; her ikisini de cevabı için 2 puan; sol el cevabı için 
3 puan almışlardır. Toplamda 13-17 puan arası alan öğrenciler sağ elli (sağlak); 18-32 puan arası alan öğrenciler iki elli ve 33-39 puan arası alan öğrenciler sol elli (solak) olarak kabul edilmiştir.

\section{Sözcük Çözümleme Becerilerini Ölçme İşlemleri}

Bu çalışmada üniversite öğrencilerinin sözcük çözümleme becerilerinin değerlendirilmesi sırasında iki farklı sözcük okuma işlemi kullanılmıştır. Bunlardan ilki anlamlı sözcük okuma işlemi iken bir diğeri anlamsız sözcük okuma işlemidir. İşlemler öncelikle Türkiye'deki farklı okuma profiline sahip olan okuyucuların sözcük okuma becerilerini değerlendirmek amacıyla yürütülmüş bir proje kapsamında geliştirilmiş ve güncellenmiştir (Güldenoğlu, 2016). Çalışma içerisinde bu işlemler, araştırmaya dâhil edilen katılımcıların sözcük okuma sırasında temel aldıkları çözümleme stratejilerinin belirlenmesi amacıyla kullanılmıştır. Aşağıda işlemlere ilişkin ayrıntılı bilgiler sunulmuştur.

\section{Anlamlı Sözcük Okuma İşlemi}

Bu çalışmada katılımcıların temel sözcük çözümleme performanslarının belirlenebilmesi için kullanılan ilk işlem anlamlı sözcük okuma işlemidir. İşlemin uygulanması sırasında katılımcılara birisi düz yazı, diğeri ise el yazısı ile yazılmış gerçek/anlamlı sözcük çiftleri sunularak olabildiğince hızlı bir biçimde (en fazla 3,5 saniye içerisinde) kendilerine sunulan sözcük çiftlerine ilişkin aynı/farklı kararını vermeleri istenmiştir (Şekil 1). Uygulama sırasında iki farklı yazı tipinin (düzyazı, el yazısı) kullanılmasıyla katılımcıların farklı yazı tiplerindeki sözcük çiftleri için aynı/farklı kararını verirken salt algıya (sadece görsel/algısal düzeye) dayanarak karar vermemeleri, bir başka deyişle bir adım öteye geçerek sözcük okuma becerilerini kullanmaları sağlanmaya çalışılmıştır (Güldenoğlu, Kargın ve Miller, 2012; Güldenoğlu, 2016; Kargin, Guldenoglu, Miller, Hauser, Rathmann, Kubus, 2011; Miller, Kargin, Guldenoglu, Rathmann, Kubus, Hauser ve Spurgeon, 2012; Miller, 2004a; Miller, 2004b; Miller, 2005b; Miller, 2006a, Miller, 2006b).

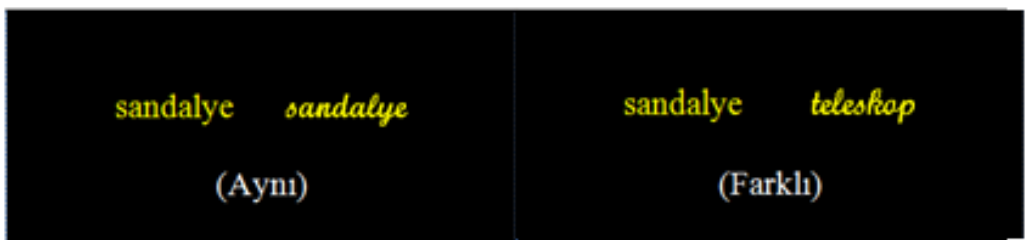

Şekil 1. Anlamlı Sözcük Çözümleme İşlemindeki İki Maddeye İlişkin Örnek Ekran Görüntüsü.

Uygulama sırasında yukarıda Şekil 1'deki ekran görüntüsünde görülen (Aynı) ve (Farklı) ifadeleri bilgisayar ekranında yer almamaktadır. Katılımcının ilk şekilde (Aynı), ikinci şekilde (Farklı) yanıtını vermesinin beklendiğini belirtmek için eklenmiştir. İlgili işlemin oluşturulmasında öncelikle gerçek hayatta karşılığ 1 olan ve tüm katılımcıların tanıdık olduğu sözcüklerin yer aldığı bir sözcük listesi oluşturulmuştur. Farklı olan sözcük çiftlerinin belirlenmesi sırasında dikkat edilen bir başka konu, farklı sözcüklerden oluşan sözcük çiftlerindeki iki sözcügün benzer harf ve hece sayılarına sahip olmasıdır. Örneğin "sandalye - teleskop" gibi anlamlı sözcük çiftlerinin oluşturulması sırasında eşleştirilen her iki sözcük de hem sekiz harften hem de üç heceden oluşmaktadır. İşlemin içerisinde toplam 42 sözcük çifti yer almaktadır (Tablo 3).

Tablo 3

Anlamlı Sözcük Okuma İşleminde Yer Alan Maddelerin Sözcük Türü ve Hece Saylsına Göre Dağılımı

\begin{tabular}{|c|c|c|c|}
\hline Hece Sayıs1 & $\mathrm{n}$ & \multicolumn{2}{|c|}{ Örnek Maddeler } \\
\hline Tek Heceli & 6 & kol - kol & $v^{*}$ \\
\hline İki Heceli & 12 & kedi - erik & $\mathrm{X}^{*}$ \\
\hline Üç Heceli & 12 & sandalye - sandalye & $v^{*}$ \\
\hline Dört Heceli & 12 & televizyon - bilgisayar & $\mathrm{X}^{*}$ \\
\hline Toplam & & \multicolumn{2}{|c|}{42 madde ( 21 'i ayn1- 21 'i farklı) } \\
\hline
\end{tabular}


Tablo 3 anlamlı sözcük okuma işleminde yer alan sözcük çiftlerinin hece sayısına göre dağılımını göstermektedir. Altı tanesi tek heceli, 12 tanesi iki, 12 tanesi üç ve 12 tanesi dört heceli olmak üzere toplam 42 sözcük çifti bulunmaktadır. Bunların 21’i aynı iki sözcükten, diğer 21'i ise farklı iki sözcükten oluşmaktadır. Örneğin bilgisayar ekranında "kol - kol" maddesi göründügünde aynı, "televizyon - bilgisayar" maddesi göründüğünde farklı yanıtını vermeleri gerekmektedir.

İşlemde yer alan tüm sözcük çiftlerinin belirlenmesinden sonra, bu sözcüklerin çalışmanın amacına uygun olup olmadığı ile sözcüklerin sahip oldukları dilbilimsel özelliklerin çalışmada ölçülmesi hedeflenen beceriler için uygun olup olmadığını görebilmek için üç Türkçe öğretmeni ile dilbilim ve okuma alanında araştırmalar yapmış iki öğretim üyesinden görüşler alınmış ve alınan geri bildirimlere göre sözcükler tekrardan düzenlenerek işleme son şekli verilmiştir. Ardından belirlenen tüm sözcükler biri düz yazı diğeri ise el yazısı olacak şekilde okullarda kullanılan el yazısı ve düzyazı fontu ile yazılarak kendi içerisinde karıştırılmış ve uygulamanın yapılacağı Display Master [(DMASTR) K.I.Forster ve J.C.Forster tarafindan geliştirilmiştir; http://www.u.arizona.edu/ kforster /dmastr/dmastr.htm adresinden erişilebilir] bilgisayar programına yüklenmiştir. $\mathrm{Bu}$ program, öğrencilerin her bir sözcük çifti için vermiş oldukları yanıtların zamanlarını ve doğruluğunu, uygulama sonrasında analiz edebilmek için otomatik olarak kayıt edebilen bir bilgisayar programıdır. Temel sözcük çözümleme becerilerinin değerlendirilmesi amacıyla kullanılacak olan bu alt işlem bir bilgisayar işlemi olduğundan, katılımcılardan işlem içerisindeki sözcük çiftlerinin aynı olduğunu düşündüklerinde sol tab tuşuna, farklı olduğunu düşündüklerinde ise sağ tab tuşuna basmaları istenmiş ve kullanılan bilgisayar programı yardımıyla katılımcıların performans zamanları ve doğrulukları uygulama sırasında bilgisayar tarafindan otomatik olarak kayıt edilmiştir (Şekil 1).

\section{Anlamsız Sözcük Okuma İşlemi}

$\mathrm{Bu}$ işlemin uygulanması sırasında ise katılımcılara birisi düz yazı, diğeri ise el yazısı ile yazılmış anlamsız sözcük çiftleri sunularak olabildiğince hızlı bir biçimde (en fazla 3,5 saniye içerisinde) kendilerine sunulan sözcük çiftlerine ilişkin aynı/farklı kararını vermeleri istenmiştir (Şekil 2). Uygulama sırasında aşağıda Şekil 2'deki ekran görüntüsünde görülen (Aynı) ve (Farklı) ifadeleri bilgisayar ekranında yer almamaktadır. Katılımcının ilk şekilde (Aynı), ikinci şekilde (Farklı) yanıtını vermesinin beklendiğini belirtmek için eklenmiştir.

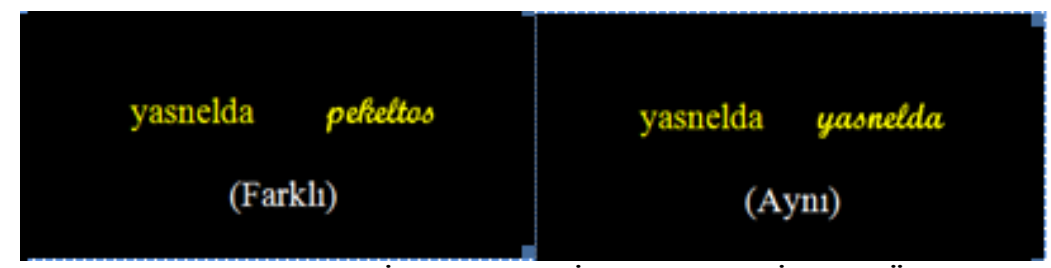

Şekil 2. Anlamlı Sözcük Çözümleme İşlemindeki İki Maddeye İlişkin Örnek Ekran Görüntüsü.

İlgili işlemin oluşturulması sırasında bir önceki işlemde (anlamlı sözcük okuma işlemi) kullanılan anlamlı sözcüklerin harfleri yer değiştirilerek üretilen anlamsız sözcükler kullanılmıştır. Yine sözcük çiftlerinin belirlenmesi sırasında farklı anlamsız sözcüklerden oluşan sözcük çiftlerindeki iki sözcüğün benzer harf ve hece sayılarına sahip olmasına ve her ne kadar anlamsız da olsa oluşturulan tüm sözcüklerin Türkçenin hece yapısına uygun olmasına dikkat edilmiştir. Örneğin "sandalye - teleskop" gibi anlamlı sözcük çiftinden oluşturulan "yasnelda - pekeltos" anlamsız sözcük çiftinde her iki sözcük de hem sekiz harften hem de üç heceden oluşmaktadır. İşlem içerisinde toplam 42 sözcük çifti yer almaktadır (Tablo 4). İşlemde kullanılan tüm sözcükler biri düz yazı diğeri el yazısı olacak şekilde, okullarda kullanılan el yazısı ve düzyazı fontu ile yazılarak, kendi içerisinde karıştırılmış ve uygulamanın yapılacağı DMASTR bilgisayar programına yüklenmiştir. Bu işlem yine bilgisayarda uygulanan bir işlem olduğundan işlem sırasında katılımcılardan sözcük çiftlerinin aynı olduğunu düşündüklerinde sol tab tuşuna, farklı olduğunu düşündüklerinde ise sağ tab tuşuna basmaları istenmiş ve kullanılan bilgisayar programı yardımıyla katılımcıların performans zamanları ve doğrulukları uygulama sırasında bilgisayar tarafından otomatik olarak kayıt edilmiştir. 
Tablo 4

Anlamsız Sözcük Okuma Isşeminde Yer Alan Maddelerin Sözcük Türü ve Hece Sayısına Göre Dağılımı

\begin{tabular}{lrrr}
\hline Hece Sayısı & $\mathrm{n}$ & \multicolumn{2}{c}{ Örnek Maddeler } \\
\hline Tek Heceli & 6 & lok - lok & $\checkmark^{*}$ \\
İki Heceli & 12 & dike - ekir & $\mathrm{X}^{*}$ \\
Üç Heceli & 12 & yasnelda - yasnelda & $\checkmark^{*}$ \\
Dört Heceli & 12 & zeyevinlot - basliyigar & $X^{*}$ \\
Toplam & & 42 madde (21'i aynı- 21'i farkl1) \\
\hline
\end{tabular}

$\checkmark^{*}:$ Belirtilen iki sözcük aynı

$\mathrm{X}^{*}$ : Belirtilen iki sözcük farklı

Tablo 4 anlamsız sözcük okuma işleminde yer alan sözcük çiftlerinin hece sayısına göre dağılımını göstermektedir. Altı tanesi tek heceli, 12 tanesi iki, 12 tanesi üç ve 12 tanesi dört heceli olmak üzere toplam 42 sözcük çifti bulunmaktadır. Bunların 21'i aynı iki sözcükten, diğer 21'i ise farklı iki sözcükten oluşmaktadır. Örneğin bilgisayar ekranında "lok - lok" maddesi göründügünde aynı, "zeyevinlot - basliyigar" maddesi göründüğünde ise farklı yanıtını vermeleri gerekmektedir.

\section{Verilerin Toplanması}

Araştırmanın uygulama evresinde ilk olarak Ankara Üniversitesi Klinik Araştırmalar Etik Kurulundan gerekli izinler alınmıştır. Ardından afiş, öğrenci toplulukları, mail grupları, sosyal medya aracılığıyla ve sınıflara gidilerek duyurular yapılmış; çalışmaya gönüllü olarak katılmak için başvuran öğrenciler listelenmiştir. Bir sonraki adımda gönüllü olanlarla bir araya gelinmiş ve uygulamanın amacı ve içeriği kısaca anlatılmıştır. Bilgilendirme sonrasında çalışmaya devam etmek isteyenlerle uygulama devam ettirilmiştir. Uygulamaların tümü katılımcıların kendi belirledikleri zaman dilimlerinde, okullarındaki sessiz bir ortamda veya Ankara Üniversitesi Tıp Fakültesi Fizyoloji Anabilim Dalındaki Nörofizyoloji laboratuvarında yaklaşık olarak 10 dakika süren bireysel oturumlarla yürütülmüş̧ür. Tüm oturumlar benzer biçimde/sırada gerçekleştirilmiştir. Oturumlarda sırasıyla bilgi formu, el tercih anketi ve sözcük okuma işlemleri bireysel olarak uygulanmıştır. Sözcük okuma işleminin uygulanması sırasında sıra etkisinin kontrol edilebilmesi amacıyla bir öğrenci anlamlı sözcüklerin olduğu işlemden başladıysa, diğer öğrenci anlamsız sözcüklerin olduğu işlemden uygulamaya başlamıştır.

$\mathrm{Bu}$ işlemler bir bilgisayar işlemi olduğundan uygulama sırasında öncelikle uygulamanın yapılacağı bilgisayar öğrencinin rahatça ulaşabileceği şekilde ayarlanmıştır. Uygulamaya geçmeden önce öğrenciye olabildiğince hızlı bir biçimde ekranda gördüğü sözcüklere ilişkin aynı/farklı kararını vermesi gerektiği açıklanmış ve ardından gerekli yönergeler sunulmuştur: Uygulamacı, bilgisayar programını başlatarak "Gördüğün gibi ekranda iki sözcük var. Senden istediğim olabildiğince hızlı şekilde ekranda gördüğün sözcüklere ilişkin aynılfarklı şekilde karar vermendir. Eğer iki sözcük aynı ise sağdaki "Tab" tuşuna (bu sırada uygulamacı sağdaki Tab tuşuna öğrencinin de görebileceği şekilde basar) eğer aynı değilse soldaki "Tab" tuşuna (bu sırada uygulamacı soldaki Tab tuşuna öğrencinin de görebileceği şekilde basar) basman gerekiyor. Bilgisayarda sunulacak olan iki sözcük yazı tipini (el yazısı-düzyazı) dikkate almadan sadece sözcüklerin okunuşunun aynı olup olmadığına göre bir tuşa basman gerekmektedir. Hazırsan uygulamayı başlatıyorum", yönergesini vermiş ve öğrenciden gelen hazırım onayı ile uygulamayı başlatmıştır. Uygulama içerisinde hemen test aşamasına geçmeden öğrencinin yapılacak olan uygulamaya alışması ve amacını anlayıp anlamadığının test edilmesi için bir alıştırma bölümü sunulmuştur. Bu bölümde öğrenciye işlemdeki maddelerde yer almayan aynı ve farklı sekiz sözcük çifti sunulmuş ve öğrenciden bu bölümü bağımsız olarak yapması istenmiştir. Ardından öğrenciye uygulamada anlaşılmayan bir yer olup olmadığı sorulmuştur. Öğrenciden gelen olumlu cevap sonrasında test aşamasına geçilmiştir. Bu aşamayı başlatmadan önce öğrenciye uygun yönerge yinelenmiştir: Uygulamacı, "Şimdi alıştırma bölümünde yaptığın aynı işlemi test aşamasındaki diğer sözcükler için de yapmalısın. Sana sunulacak sözcük çiftlerinin aynı olup olmadığına göre uygun olan tuşa olabildiğince hızlı bir şekilde basmalısın. Eğer bir soruda yanlış yaptığını fark edersen durma ve diğer sorularla dikkatlice devam et, hazırsan başlatıyorum”, diyerek 
öğrenciden gelen olumlu yanıt sonrasında asıl uygulamayı başlatmıştır. Uygulama bittikten sonra öğrenciye katılımı için teşekkür edilmiş ve sürece son verilmiştir.

\section{Verilerin Analizi}

İşlemler sırasında katılımcıların anlamlı ve anlamsız sözcüklerin her biri için verdiği yanıtlar süre (ms) ve doğruluk yönünden bilgisayar programına otomatik olarak kaydolmuştur. Bu durumda her bir katılımcı için biri ortalama yanıt verme süresi; diğeri doğruluk/yanlışlık durumu olmak üzere iki değerlendirme verisi elde edilmiştir.

Çalışmanın veri toplama aşamasından sonra, analizlerin yapılabilmesi için öncelikle toplanan tüm veriler uygun șekilde bilgisayar ortamında birleștirilmiș, ardından SPSS 20.0 paket programı yardımıyla analiz edilmiştir. Çalışma içerisinde yapılan analizler iki aşamada gerçekleştirilmiştir. İlk aşamada çalışmaya katılan öğrenci gruplarının sözcük okuma puanlarının ve sürelerinin karşılaştırılabilmesi için iki ayrı MANOVA (GLM- ANOVA) uygulanmıştır. İkinci aşamada ise, öğrencilerin el tercihlerinin sözcük okuma işlemlerinin uygulanması sırasında etkili olup olmadığı iki ayrı ANOVA uygulanarak belirlenmeye çalışılmıştır. Yapılan analizlere ilişkin detaylı bilgiler ve analizlerden elde edilen sonuçlar çalışmanın bulgular bölümünde ayrıntılı olarak sunulmuştur.

\section{Bulgular}

Bu çalışmada sözcük çözümleme becerilerinin değerlendirilmesi için öğrenci gruplarının iki farklı türdeki (anlamlı ve anlamsız sözcükler) sözcüklere yönelik çözümleme performansları hem hız hem de doğruluk oranları üzerinden karşılaştırmalı bir şekilde incelenmiştir. Analizler hem çözümleme hızı hem de doğruluk oranları açısından ayrı ayrı öğrenci gruplarının (sayısal- sözel puandan gelenler) deneklerarası faktör, sözcük türü etkisinin (anlamlı ve anlamsız sözcük) ise denekleriçi faktör olarak belirlendiği iki ayrı iki faktörlü MANOVA ile gerçekleştirilmiştir. Aşağıda öncelikle çözümleme hızı ardından da doğruluk oranlarına ilişkin elde edilen sonuçlar sırasıyla Tablo 5 ve Tablo 6' da ayrıntılı olarak sunulmuştur.

İlk olarak araştırmaya katılan tüm öğrencilerin, sözcük çözümleme hız ortalamalarında, iki farklı sözcük türüne göre anlamlı bir farklılık olup olmadığına bakılmış ve öğrencilerin sözcük çözümleme hızlarında sözcük türlerine göre istatistiksel olarak anlamlı bir farklılık olduğu bulunmuştur $(\mathrm{F}(1,266)=554,90, \mathrm{p}<0,01, \eta 2=0,67)$. Elde edilen etki büyüklüğü incelendiğinde, yüksek düzeyde etki büyüklüğü olduğu ve öğrencilerin bir sözcük türünü diğerine göre daha hızlı çözümledikleri anlaşılmaktadır. Bu sonuca göre Tablo 5 incelendiğinde, öğrencilerin toplamda anlamlı sözcükleri anlamsız sözcüklere göre daha hızlı bir şekilde çözümledikleri görülmektedir.

İkinci olarak sayısal ve sözel alandan gelen öğrenci gruplarının sözcük çözümleme hız ortalamaları arasında anlamlı bir farklılık olup olmadığına bakılmış ve gruplar arasında istatistiksel olarak anlamlı bir farklılık olmadığı bulunmuştur $(\mathrm{F}(1,266)=1,48, \mathrm{p}>0,05, \eta 2=0,00)$.

Tablo 5 incelendiğinde, toplamda her iki grupta yer alan öğrencilerin her iki sözcük türünde de birbirlerine benzer performans gösterdikleri görülmüştür. Öğrenci gruplanı ile sözcük türü arasında anlamlı bir ortak etkinin olmayışı $\left(\mathrm{F}(1,266)=0,86, \mathrm{p}>0,05, \eta^{2}=0,00\right)$ ise öğrenci gruplarına ilişkin ortaya çıkan bu benzerliğin hem anlamlı hem de anlamsız sözcükler için geçerli olduğunu göstermektedir.

Tablo 5

Grupların Sözcük Çözümleme Hızına İlişkin MANOVA Sonuçları

\begin{tabular}{lrrr}
\hline Değişkenler & $\mathrm{F}$ & $\mathrm{p}$ & $\eta^{2}$ \\
\hline Sözcük türü & 554,90 & 0,00 & 0,67 \\
Sözcük türü * Grup & 0,86 & 0,35 & 0,00 \\
\hline
\end{tabular}




\begin{tabular}{lrrr}
\hline Anlamlı Sözcükler & & & \\
\hline Grup & $\bar{X}$ & $\mathrm{Sd}$ & $\mathrm{n}$ \\
Sayısal & 829,44 & 144,97 & 133 \\
Sözel & 814,11 & 145,19 & 135 \\
Toplam & 821,72 & 145,02 & 268 \\
\hline Anlamsiz Sözcükler & & & $\mathrm{n}$ \\
\hline Grup & $\bar{X}$ & $\mathrm{Sd}$ & 133 \\
Sayısal & 1084,27 & 226,50 & 135 \\
Sözel & 1049,62 & 220,37 & 268 \\
Toplam & 1066,82 & 223,69 & \\
\end{tabular}

Yukarıda sunulan analiz sonuçlarına birlikte bakıldığında, sonuçlar öncelikle her iki öğrenci grubunun da sözcük çözümlemede benzer çözümleme hızlarına sahip olduklarını fakat sözcük türleri ayrı ayrı düşünüldügünde ise her iki grubun da kendilerine tanıdık gelen anlamlı sözcükleri daha önce karşılaşmadıkları anlamsız sözcüklere göre daha hızlı çözümlediklerini göstermiştir.

Öncelikle araştırmaya katılan tüm öğrencilerin, sözcük çözümleme puan ortalamalarında, iki farklı sözcük türüne göre anlamlı bir farklılık olup olmadığına bakılmış ve öğrencilerin sözcük çözümleme puan ortalamalarında sözcük türlerine göre istatistiksel olarak anlamlı bir farklılık olduğu bulunmuştur $(F(1,266)=15,45, p<0,01, \eta 2=0,05)$. Elde edilen etki büyüklüğü incelendiğinde, her ne kadar orta düzeyde bir etki büyüklüğü olduğu görülse de, sonuçlara göre öğrencilerin bir sözcük türünü diğerine göre daha doğru çözümledikleri anlaşılmaktadır. Bu sonuca göre Tablo 6 incelendiğinde, öğrencilerin toplamda anlamlı sözcükleri anlamsız sözcüklere göre az farkla daha doğru çözümledikleri görülmektedir.

İkinci olarak sayısal ve sözel alandan gelen öğrenci gruplarının sözcük çözümleme doğruluk ortalamaları arasında anlamlı bir farklılık olup olmadığına bakılmış ve gruplar arasında istatistiksel olarak anlamlı bir farkl11ık olmadığ1 bulunmuştur $(\mathrm{F}(1,266)=1,65, \mathrm{p}>0,05, \eta 2=0,00)$. Tablo 6 incelendiğinde, toplamda her iki grupta yer alan öğrencilerin her iki sözcük türünde de birbirlerine benzer performans gösterdikleri görülmüştür. Öğrenci grupları ile sözcük türü arasında anlamlı bir ortak etkinin olmayış1 $(F(1,266)=0,64, p>0,05, \eta 2=0,00)$ ise öğrenci gruplarına ilişkin ortaya çıkan bu benzerliğin hem anlamlı hem de anlamsız sözcükler için geçerli olduğunu göstermektedir.

Tablo 6

Grupların Sözcük Çözümleme Doğruluklarına İlişsin MANOVA Sonuçları

\begin{tabular}{lrrr}
\hline Değişkenler & $\mathrm{F}$ & $\mathrm{p}$ & $\eta^{2}$ \\
\hline Sözcük türü & 15,45 & 0,00 & 0,05 \\
Sözcük türü * Grup & 0,64 & 0,42 & 0,00 \\
\hline Anlamlı Sözcükler & & & $\mathrm{N}$ \\
\hline Grup & $\bar{x}$ & $\mathrm{Sd}$ & 133 \\
Sayısal & 39,71 & 2,07 & 135 \\
Sözel & 40,05 & 1,65 & 268 \\
Toplam & 39,88 & 1,87 & $\mathrm{n}$ \\
\hline Anlamsız Sözcükler & & & 133 \\
\hline Grup & $\bar{x}$ & $\mathrm{Sd}$ & 135 \\
Sayısal & 39,30 & 2,01 & 268 \\
Sözel & 39,44 & 1,68 & \\
Toplam & 39,37 & 1,85 & \\
\hline
\end{tabular}

Yukarıda sunulan analiz sonuçlarına birlikte bakıldığında, sonuçlar öncelikle her iki öğrenci grubunun da sözcük çözümlemede benzer çözümleme doğruluklarına sahip olduklarını, fakat sözcük 
türleri ayrı ayrı düşünüldüğünde her iki grubun da kendilerine tanıdık gelen anlamlı sözcükleri daha önce karşılaşmadıkları anlamsız sözcüklere göre daha doğru çözümlediklerini göstermiştir.

$\mathrm{Bu}$ çalışmada katılımcıların sözcük çözümleme performansları bir bilgisayar programı aracılığıyla değerlendirilmiştir. Programın uygulanması sırasında okuyuculardan ekranda gördükleri sözcük çiftlerinin aynı olup olmadığına karar verirken kararlarını bilgisayar üzerindeki iki tuşu kullanarak göstermeleri istenmiştir. Tuşlardan biri sağ tab tuşu iken diğeri ise sol tab tuşudur. Katılımcılardan uygulama sırasında her iki ellerini de tuşlar üzerine koymaları ve ekranda gördükleri sözcük çiftlerinin aynı olup olmadığına göre uygun taraftaki eliyle tuşa basmaları istenmiştir. Böyle bir değerlendirmede katılımcıların el tercihlerinin yapılan değerlendirme üzerinde etkili olup olmadığının belirlenmesi önemlidir. Bu nedenle çalışma içerisinde hem sözel hem de sayısal grupta yer alan katılımcıların sözcük çözümleme performansları el tercihleri (sol, sağ el) temelinde ayrı ayrı iki farklı GLM-ANOVA ile analiz edilmiştir. Öncelikle çözümleme hızı açısından incelendiğinde, hem sayısal hem de sözel grupta sağ ve sol el tercihi olan katılımcıların performans hızları incelenmiş ve sonuçlar hem sayısal $(F(1,133)=0,93, p>0,05, \eta 2=0,00)$ hem de sözel $(F(1,131)=0,00, p>0,05$, $\eta 2=0,00)$ grupta yer alan öğrencilerin el tercihlerinin sözcük çözümleme hızları açısından anlamlı bir fark yaratmadığı görülmüştür. Benzer bulgular doğruluk oranları için de ortaya çıkmıştır. Hem sayısal hem de sözel grupta sağ ve sol el tercihi olan katılımcıların doğruluk oranları incelenmiş ve sonuçlar hem sayisal $(F(1,133)=0,15, p>0,05, \eta 2=0,00)$ hem de sözel $(F(1,131)=0,06, p>0,05, \eta 2=0,00)$ grupta yer alan öğrencilerin el tercihlerinin sözcük çözümleme doğrulukları açısından anlamlı bir fark yaratmadıği görülmüştür.

\section{Sonuç, Tartışma ve Öneriler}

$\mathrm{Bu}$ çalışmada üniversite öğrencilerinin sözcük çözümleme stratejilerini incelemek amaciyla 271 gönüllü öğrenciye iki farklı sözcük çözümleme işlemi uygulanmıştır. Uygulama sonrasında katılımcılar, okumakta olduğu bölümlerin puan türlerine göre sayısal ve sözel olmak üzere iki gruba ayrılarak anlamlı ve anlamsız sözcük çözümleme puanları analiz edilmiş ve karşılaştırılmıştır.

Araştırma içerisinde üç temel hipotez test edilmiştir. Çalışmada test edilen ilk hipotez "Çalışmaya katılan tüm öğrenciler bir grup olarak düşünüldügünde, öğrenciler anlamlı sözcükleri anlamsız sözcüklere göre hem daha hızlı hem de daha doğru çözümleyeceklerdir." şeklindedir ve elde edilen sonuçlara göre bu hipotezin doğrulandığı görülmektedir. Alanyazında okuyucuların sözcük dağarcıklarında karşılığı olan, tanıdık oldukları sözcükleri daha doğru ve daha hızlı çözümlediklerini gösteren çalışmalar bulunmaktadır (Coch, Mitra ve George, 2012; Martin, Nazir, Thierry, Paulignan ve Démonet. 2006; Miller, 2005; Ripamonti, Luzzatti, Zoccolotti ve Traficante, 2018). Çalışmalarda anlamsız sözcük çözümlemedeki yavaşlığın, okuyucuların bu kategorideki sözcüklerle daha önce hiç karşılaşmamış olmaları nedeniyle sesbilgisel çözümleme yapma gereksiniminden kaynaklandığı vurgulanmaktadır (Jackson ve Coltheart, 2001). Alanyazında sesbilgisel çözümlemenin sözcükleri hecelerine veya seslerine bölmeyi gerektiren bilişsel bir süreç olması nedeniyle, otomatikliğin ön planda olduğu ortografik çözümlemeye göre daha fazla zaman alan bir süreç olduğu sıkça belirtilmektedir (Güldenoğlu vd., 2014; Miller, 2005). Bu görüşlerden yola çıkıldığında, bu çalışmadan elde edilen sonuçların önceki çalışmalardan elde edilen sonuçlarla tutarlı olduğu söylenmelidir. Daha açık bir ifadeyle, bu çalışmaya katılan okuyucuların kendilerine tanıdık gelen anlamlı sözcükleri çözümlerken daha hızlı olmaları aslında onların bu kategoride ortografik çözümleme stratejisini kullandıklarını, kendilerine tanıdık gelmeyen anlamsız sözcükler sırasında ise sesbilgisel çözümlemelere başvurduklarını doğrulamaktadır. Sonuçlara çözümleme doğruluğu açısından bakıldığında ise sözcük türünün doğruluk üzerinde anlamlı bir etki yaratmadığı, çalışmaya dahil edilen okuyucuların hem üniversite öğrencileri olmaları hem de sözcük düzeyinde çözümleme için erişkin düzeye ulaşmış olmaları nedeniyle her iki kategorideki sözcükleri de benzer doğruluk oranlarında çözümledikleri görülmektedir. Bu sonuçlar ileriki analizler için önkoşul niteliği taşımakta olup, temelde iki önemli konuyu gündeme getirmektedir. Bunlardan ilki, çalışma içerisinde bu aşamada elde edilen sonuçların, örneklem alma biçiminden/sürecinden değil, tamamen okuyucuların sözcük çözümleme stratejilerinden kaynaklandığ 1 , bir diğeri ise çalışma içerisinde kullanılan sözcük çözümleme işlemlerinin bir gruba ya da sözcük kategorisine ilişkin avantaj sağlamadığıdır. Bu iki 
durum hem çalışmadan elde edilen verilerin güvenirliğini hem de kullanılan işlemlerin geçerliğini olumlu yönde etkileyen durumlardır.

Sözcük çözümleme performansının değerlendirilmesi söz konusu olduğunda karşımıza gelen önemli bir başka konu ise okuma deneyimidir. Yapılan çalışmalarda yaşla beraber artan okuma deneyiminin sözcük çözümleme üzerinde olumlu etkileri olduğu sıkça vurgulanmaktadır (Breznitz. 1997; Erden vd., 2002; Güldenoğlu vd., 2014, 2015; Miller, 2005b). Her ne kadar ilk bakışta çalışmaya katılan öğrencilerin üniversite çağına gelene kadar pek çok çalışma ve sınavdan geçtiği ve bu nedenle deneyimli okuyucu oldukları düşünülse de, çalışmada karşılaştırılan iki gruptan birinin sözel bölüm öğrencileri olması, bu konunun performanslar üzerinde etkili olabileceğini düşündürmektedir. $\mathrm{Bu}$ çalışmada sözel bölümden gelen öğrencilerin hem üniversite sinavına hazırlanma sürecinde, hem de okudukları bölüm nedeniyle sayısal bölümden gelenlere oranla daha fazla okuma yaptıkları ve okuma deneyimlerinin daha fazla olacağ çözümlemede bir avantaj yaratabileceği düşünülmektedir. Bu görüşten hareketle bu çalışmada ikinci bir hipotez ("sözel bölümlerde öğrenim gören üniversite öğrencilerinin sayısal bölümlerdekilere göre her iki kategoride yer alan sözcükleri hem daha hızlı hem de daha doğru çözümleyeceklerdir") test edilmiştir. Bu hipotezi test etmek amacıyla çalışmaya sözel ve sayısal bölümlerden dahil edilen öğrencilerin sözcük çözümleme performansları karşılaştırmalı olarak incelenmiştir. Bulgular, bu hipotezin doğrulanmadığını ve sayısal ve sözel bölümlerden gelen öğrencilerin sözcük çözümleme hızları ve doğruluklarının anlamlı bir şekilde farklılaşmadığını göstermiştir. Halbuki alanyazında okuyucuların okuma deneyimlerinin artması ile sözcükleri daha hızlı ve daha doğru çözümleyeceklerini bildiren araştırmalar bulunmaktadır (Breznitz, 1997; Erden vd., 2002; Güldenoğlu vd., 2014; Miller 2005a; Stanovich, Cunningham ve Feeman, 1984). Bu çalışmaların çoğunlukla ilkokul ve ortaokul öğrencilerine odaklandığı; bu yaşlarda sınıf düzeyinin artması ile öğrencilerin okuma deneyimlerinin arttığ 1 ve sözcükleri daha hızlı çözümledikleri görülmektedir. Araştırmamızda değerlendirilen grubun yetişkin okuyucular olmasının, çalışmada elde edilen bulguların diğer çalışmalardaki bulgulardan farklılaşmasına yol açtığı düşünülmektedir. Hem grubun özellikleri hem de ortaya çıkan çözümleme performansları göz önüne alındığında, çalışma içerisinde iki farklı konunun vurgulanmasın önemlidir. Bunlardan ilki; çalışmada kullanılan işlemlerin temel okuma düzeyi olan sözcük düzeyinde olması, bir diğeri ise işlemlerde yer alan sözcüklerin yalın halde (eksiz olarak) okuyuculara sunulmasıdır. Bu çalışmada kullanılan tüm sözcüklerin dilbilimsel açıdan basit bir yapıda sunulmuş olmasının, gruplar arasında beklenen farkın oluşmamasında etkili olduğu düşünülmektedir. Özellikle anlamsız sözcüklerin çözümlenmesinde beklenen farkların oluşmamasında Türkçenin saydam ortografik yapısının (harf - ses dönüşümleri açısından birebir eşleme özelliğinin ve her harfin/hecenin sadece bir sesletim karşılığı olmasının) sonuçlar üzerinde etkili olmuş olabileceği düşünülmektedir. Her ne kadar anlamsız sözcüklerin katılımcıların sesbilgisel dağarcıklarında bir karşılıkları olmasa da, saydam ortografik yapının getirdiği avantaj nedeniyle okuyucuların sözcükleri uygun şekilde hecelerine ayırdıklarında doğru çözümlemeye kolayca erişebilecekleri açıktır (Güldenoğlu, 2016). Bu nedenle bu sözcük türünde çözümlemenin sesbilgisel açıdan hece düzeyi üzerine çıkmadığı, bunun sonucunda da okuma deneyimine bağlı olarak sözel alanlardan gelen katılımcılara yönelik beklenen sözcük çözümleme performans avantajlarının oluşmadığı söylenmelidir. Hâlbuki okuyucuların günlük yaptıkları okumalar üzerinde hem çözümleme hem de bunun sonucu olarak ortaya çıkan anlama performanslarını etkileyen önemli bir durum ise Türkçenin oldukça karmaşık morfolojik (hem karmaşık morfolojik hem de morfo-sentaktik yapısı) yapısıdır (Aksan, 2005). Özellikle, eklemlemeli bir dil olan Türkçe'nin karmaşık morfolojik yapısı (bir sözcügün sayısız ek alma durumu) düşünüldüğünde, okuyucuların çözümleme sırasında çoğunlukla birden çok ek almış sözcüklerle ve bu sözcüklerden oluşan cümlelerle karşılaştıkları, bu durumun da onların çözümleme ile okuduğunu anlama performanslarını doğrudan etkilediği görülmektedir. Cümle ve metin okuma, içeriğinde sözcük çözümleme, sözdizimi, morfoloji, akıcılık, anlama ve okuma deneyimi gibi birçok dilsel ve bilişsel beceriyi barındırmaktadır. İçeriği düşünüldüğünde, bu becerilerin sözel olanların lehine anlamlı farklılaşabileceği düşünülmektedir. Bu açıdan bakıldığında aslında sözel bölümde okuyan öğrencilerin okuma deneyimlerinin ekli ve karmaşık morfolojik yapıları barındıran cümle ve metinlerde daha ön plana çıkacağı ve diğerlerine göre daha başarılı olabilecekleri söylenebilir. 
$\mathrm{Bu}$ çalışmada öğrencilerin sözcük çözümleme becerilerinin değerlendirilmesinde kullanılan işlemlerin bilgisayar destekli işlemler olması ve işlemlerin uygulanması sırasında öğrencilerin sözcük çözümlemeye ilişkin tepkilerini sağ ve sol işaret parmaklarıyla ilgili tuşlara basarak vermeleri, öğrencilerin el tercihlerinin sonuçlar üzerinde etkili olabileceğini gündeme getirmiştir. El tercihlerinin iki eli de kullanmayı gerektiren bu tarz işlemlerde etkili olabileceği görüşünden yola çıkarak, çalışma içerisinde öğrencilere bir el tercihi anketi uygulanmış ve öğrencilerin sözcük çözümleme performanslarının el tercihlerine göre farklılaşıp farklılaşmadığı, bir başka deyişle el tercihlerinin sözcük çözümleme performansları üzerinde etkili olup olmadığı analiz edilmiştir. Analiz sonuçları incelendiğinde, öğrencilerin el tercihlerinin sözcük çözümleme performansları üzerinde anlamlı bir etkisinin olmadığı görülmüştür. Bu durum ise yine çalışmada elde edilen sonuçların güvenirliğini arttıran önemli bir unsurdur.

Sonuç olarak bu çalışmadan elde edilen tüm bulgular birlikte düşünüldüğünde, öncelikle çalışma sonuçlarının alanyazındaki temel okuma kuramları (Sesbilgisel ve Çift Yönlü Sözcük Okuma Kuramları) ile tutarlı olduğu görülmektedir. Diğer taraftan çalışma içerisinde gruplararası ortaya çıkan sözcük çözümleme bulgularının Türkçenin tamamen saydam ortografik yapısından dolayı, alanyazında bu konuya ilişkin farklı dillerde gerçekleştirilmiş diğer çalışmalardan farklılaştığı görülmektedir. Bu çalışma farklı okuma profiline sahip olan okuyucuların sözcük çözümleme sırasındaki beyin dalgalarının incelenmesine yönelik tıp alanında yapılan bir uzmanlık tezinin ilk aşamasından üretilmiş olup Türkçe gibi tamamen saydam bir ortografide deneyimli okuyucularla gerçekleştirilmiş ilk çalışmadır. Bu özelliğinden dolayı bu çalışmanın ileride bu konuda yürütülecek farklı çalışmalara öncülük edebileceği düşünülmektedir.

$\mathrm{Bu}$ çalışmada okuyuculara iletilmesi gereken bazı sınırlılıklar bulunmaktadır. İlk olarak, araştırma sınırlı sayıdaki öğrenciyle gerçekleştirilmiştir, bu nedenle ileriki çalışmalarda daha fazla kişiden veri toplanarak sonuçların genellenebilirliği incelenebilir. İkincisi, çalışma içerisinde yapılan ölçümler sözcük düzeyinde ve sadece çözümleme performansları ile sınırlıdır. Bu nedenle ileriki çalışmalarda çözümlemeye ek olarak öğrencilerin cümle ve metin anlama performanslarının da incelenmesi, onların okuma profillerine ilişkin önemli bilgiler sunacaktır. Üçüncüsü, bu çalışmada katılımcıların tamamının merkezi bir sınavdan geçerek üniversiteye yerleşmiş olmalarından dolayı grubun homojenliği sağlanmakla beraber, sınavda başarılı olamayan yetişkinlerin araştırma grubumuza girmedikleri unutulmamalıdır. Araştırma grubunda olmayan bu kesimin sınavdaki başarısızlıkları okuma becerilerindeki bir yetersizlikten kaynaklanıyor olabilir, ancak bunun belirlenebilmesi için yeni çalışmaların kurgulanmasına ihtiyaç vardır. Bu nedenle ileriki çalışmalarda sınav başarısına göre ayrılmış iki grubun okuma ve okuduğunu anlama performanslarının karşılaştırmalı olarak incelenmesi önerilebilir.

Açıklama ve Teşekkür: Bu çalışma üçüncü yazarın danışmanlığında birinci yazar tarafından yapılan "İyi ve kötü okuyan erişkinlerde hemisferler arası iletimin elektroensefalografi yöntemi ile değerlendirilmesi" başlıklı tıpta uzmanlık tezinden türetilmiştir. Ankara Üniversitesi Bilimsel Araştırma Projeleri (BAP) Koordinatörlüğü tarafından desteklenmiştir (Proje no: 18L0230001).

Çalışmaya katkılarından dolayı sayın Prof. Dr. Tevhide Kargın'a teşekkür ederiz. 


\section{Kaynaklar}

Aksan, D. (2005). Türkiye Türkçesinin dünü, bugünü, yarını. Ankara: Bilgi Yayınevi.

Breznitz, Z. (1997). Reading rate acceleration: Developmental aspects. The Journal of Genetic Psychology, 158(4), 427-441.

Chapman, L. and Chapman Jp. (1987). The measurement of handedness. Brain and Cognition, 6, 175183.

Coch, D., Mitra, P. and George, E. (2012). Behavioral and ERP evidence of word and pseudoword superiority effects in 7- and 11-year-olds. Brain research, 1486, 68-81.

Ehri, L. C. (2002). Phases of acquisition in learning to read words and implications for teaching. Stainthorp, R. and Tomlinson, P. (Eds.), Learning and teaching reading. London: British Journal of Educational Psychology Monograph Series, 2, (p.7-28).

Erden, G., Kurdoğlu, F. ve Uslu, R. (2002). İlkögretim okullarına devam eden Türk çocuklarının sınıf düzeylerine göre okuma hızı ve yazım hataları normlarının geliştirilmesi. Türk Psikiyatri Dergisi, 13(1), 5-13.

Frost, R. (1998). Toward a strong phonological theory of visual word recognition: True issues and false trials. Psychological Bulletin. 123, 71-99.

Frost, R. (2006). Becoming literate in Hebrew : The Grain-Size hypothesis and semitic orthographic systems. Developmental Science, 9(5), 439-440.

Gough, P. B. and Tunmer, W. E. (1986). Decoding, reading and reading disability. Remedial and Special Education, 7, 6-10.

Güldenoğlu, İ. B., Kargın, T. ve Miller, P. (2012). İyi ve zayıf okuyucuların kelime 1şlemleme ve okuduğunu anlama becerilerinin karşılaştırılmalı olarak incelenmesi. Kuram ve Uygulamada Eğitim Bilimleri, 12(4), 2807-2828.

Güldenoğlu, B., Kargın, T. ve Miller, P. (2014). İşiten ve işitme engelli okuyucuların kelime işlemleme becerilerinin karşılaştırmalı olarak incelenmesi. Türk Psikoloji Dergisi, 29 (73), 1838.

Güldenoğlu, B., Kargın, T. ve Miller, P. (2015). Okuma güçlüğü olan ve olmayan öğrencilerin cümle anlama becerilerinin incelenmesi. Türk Psikoloji Dergisi, 30(76), 82-96.

Güldenoğlu, B. (2016). The effects of syllable-awareness skills on the word-reading performances of students reading in a transparent orthography. International Electronic Journal of Elementary Education, 428(3), 425-442.

Güzel, R. (1998). Alt özel sinıflardaki öğrencilerin sesli okudukları öyküyü anlama becerilerini kazanmalarında doğrudan ögretim yöntemiyle sunulan bireyselleştirilmiş okuduğunu anlama materyalinin etkililiği. Doktora Tezi. Gazi Üniversitesi, Eğitim Bilimleri Enstitüsü, Ankara.

Hoover, W. A. and Gough, P. B. (1990). The simple view of reading. Reading and Writing: An Interdisciplinary Journal, 2, 127-160.

Jackson, N. E. and Coltheart, M. (2001). Routes to reading success and failure: Toward an integrated cognitive psychology of atypical reading. Philadelphia, PA, US: Psychology. 
Karasar, N. (2005). Bilimsel araştırma yöntemi. Ankara: Nobel.

Kargin, T., Guldenoglu, I. B., Miller, P., Hauser, P., Rathmann, C. and Kubus, O. (2011). Differences in word processing skills of deaf and hearing individuals reading in different orthographies. Journal of Developmental and Physical Disabilities, 24(1), 65-83.

Lewis, RB. And Doorlag, DH. (1983). Teaching special studies in mainstream. Ohio: Charles E. Merill Publishing Company.

Martin, C. D., Nazir, T., Thierry, G., Paulignan, Y. and Démonet, J.F. (2006). Perceptual and lexical effects in letter identification: An event-related potential study of the word superiority effect. Brain Research, 1098(1), 153-60.

Miller, P. (2004a). Processing of written word and non-word visual information by individuals with prelingual deafness. Journal of Speech, Language, and Hearing Research, 47, 990-1000.

Miller, P. (2004b). Processing of written words by individuals with prelingual deafness. Journal of Speech, Language, and Hearing Research, 47, 979-989.

Miller, P. (2005a). Reading experience and changes in the processing of letters, written words, and pseudohomophones: Comparing fifth-grade students and university students. The Journal of Genetic Psychology, 166(4), 407-434.

Miller, P. (2005b). Reading comprehension and its relation to the quality of functional hearing: Evidence from readers with different functional hearing abilities. American Annals of the Deaf, 150, 305-323.

Miller, P. (2006a). What the processing of real words and pseudohomophones tell about the development of orthographic knowledge in prelingually deafened individuals. Journal of Deaf Studies and Deaf Education, 11, 21-38.

Miller, P. (2006b). What the visual word recognition skills of prelingually deafened readers tell about their reading comprehension problems. Journal of Development and Physical Disabilities, 18, 91-121.

Miller, P., Kargin, T., Guldenoglu, B., Rathmann, C., Kubus, O., Hauser, P. and Spurgeon, E. (2012). Factors distinguishing skilled and less skilled deaf readers: Evidence from four orthographies. The Journal of Deaf Studies and Deaf Education, 17(4), 439-462. https://doi.org/10.1093/deafed/ens022.

Moates, L. C. (2000). Speech top rint: Language essentials for teachers. Baltimore: Brookes.

Nalcaci, E., Kalaycioglu, C., Gunes, E. and Cicek, M. (2002). Reliability and validity of a handedness questionnaire. Türk Psikiyatri Dergisi, 13(2), 99-106.

Ölçme, Seçme ve Yerleştirme Merkezi. (2018). 2018 Yükseköğretim Kurumları Sınavı Kılavuzu. Erişim adresi: https://dokuman.osym.gov.tr/pdfdokuman/2018/YKS/KILAVUZ 28062018.pdf

Perfetti, C. A. (1985). Reading ability. New York: Oxford University Press.

Paap, K. R. and Noel, R. W. (1991). Dual-route models of print to sound: Still a good horse race. Psychological-Research, 53, 13-24. 
Ramus, F., Pidgeon, E. and Frith, U. (2003). The relationship between motor control and phonology in dyslexic children. Journal of Child Psychology and Psychiatry, 44, 712-722.

Ripamonti, E., Luzzatti, C., Zoccolotti, P. and Traficante, D. (2018). Word and pseudoword superiority effects: Evidence from a shallow orthography language. Quarterly Journal of Experimental Psychology, 71(9), 1911-1920. https://doi.org/10.1080/17470218.2017.1363791

Ross, A. O. (1976). Psychological aspects of learning disabilities and reading disorders. NY: MacGraw-Hill Book Company.

Samuels, S. J. and Farstrup, A. (2006). Reading fluency: The forgotten dimension of reading success. Newark: International Reading Association.

Stanovich, K. E., Cunningham, A. E. and Feeman, D. J. (1984). Relation between early reading acquisition and word decoding with and without context: A longitudinal study of first-grade children. Journal of Educational Psychology, 76 (4), 668-677. http://dx.doi.org/10.1037/0022$\underline{0663.76 .4 .668}$

Therrien, W. J. (2004). Fluency and comprehension gains as a result of repeated reading: A metaanalysis. Remedial and Special Education, 25(4), 252-61.

Tunmer, W. E. (2008). Recent developments in reading intervention research: Introduction to special issue. Reading and Writing, 21, 299-316. doi: 10.1007/s11145-007-9108-4.

Yüksek Öğretim Kurulu. (2018). Yükseköğretim kurumları sınavı puan türleri tablosu-2018. 01.09.2018 tarihinde http://www.yok.gov.tr/documents/10279/31137395/yuksekogretim_kurumlari_sinavi_puan_tu rleri.pdf adresinden erişilmiştir. 


\section{Extended Abstract}

\section{Introduction}

Reading is the process of achieving meaning through written symbols. When one considers that the most important objective of reading is to comprehend, it is necessary for readers to decode the words in written texts in an accurate way to achieve this objective. After decoding, readers should properly comprehend the words they have decoded. Although it is not adequate on its own for successful reading performance, the literature shows that word decoding skill is one of the important predictors of reading comprehension and that it is one of the basic prerequisite skills needed in order to switch into the comprehension stage of the reading process.

When analyzing word-reading theories where readers' word decoding processes are described in detail, we see that these processes are explained in the literature with two basic word-reading theories. The Phonological Word Reading Theory states that the essence of reading occurs through phonological decoding. Readers first decode the phonetic structure blocks (letter and syllable combinations). Later they associate these phonologically decoded words with meanings in their own phonological lexicon. The Dual-Route Cascaded Word Reading Model, however, claims that readers decode words by adopting two different strategies (phonetic or orthographic). According to this theory, during the utilization of the first way, which is based on phonetic foundations, readers decode the words by dividing them into phonetic structure blocks as mentioned in the previous theory. However, during utilization of the orthographic way, which is based on a phonological lexicon, they rely on a process that connects the letter strings of written words with permanent orthographic knowledge (representation) that mediates their meaning. According to this theory, when readers encounter words that are not in their personal phonological lexicon, they use the phonetic way. When they have come across the same word a few times, however, they use the orthographic way, since they now have a prior input into their phonological lexicon in regard to these words.

It is obvious that fluent reading skills are important in academic achievement. These skills include fast and accurate reading. In Turkey, the students in high school have to choose one of the programs that are given quantitative or verbal weighted education. The graduate programs in the university they chose are also linked to this situation. Due to this condition, it is expected that the reading skills of the students from verbal graduate programs are better than the students from quantitative graduate programs.

Aim of the study; This is a descriptive study aiming to comparatively examine the main word decoding strategies of university students from quantitative and verbal graduate programs. In line with this general objective, word decoding strategies of university students involved in the study have been analyzed under three basic research hypotheses;

Hypothesis 1 . When all the students are considered collectively, students will be faster and make fewer mistakes when reading real- words than reading pseudo-words.

Hypothesis 2. Students from verbal graduate programs will be faster and will make fewer mistakes in reading both real-words and pseudo-words than students from quantitative programs.

Hypothesis 3. Differences in speed and accuracy between real-words and pseudo-words will be higher in students from quantitative programs than students from verbal graduate programs.

\section{Method}

A total of 271 (135 quantitative graduate program; 136 verbal graduate program) university students were enrolled in the current study and the word decoding skills (accuracy and decoding speed) were evaluated with two different processes that include decoding of real- words and decoding of pseudo-words. For this purpose, the real- word and pseudo-word pairs are used. The pseudo-words are composed by replacing the letters of the real- words. One of the word in the pairs is written in Times New Roman scripts and the other one is written in Handwriting scripts. The word pairs were 
read silently by the students. They were expected to quickly decide whether the word pairs were the same or not. They read the words via computer and press the keys to answer. All the answers were saved as accuracy and reaction time in milliseconds. Data was analyzed by using variance analysis (GLM-ANOVA) and two factor MANOVA (GLM-MANOVA) tests.

\section{Result}

The results showed that students in both groups decoded the real-words faster than the pseudowords. There was no significant difference between the two groups in terms of their word decoding performance.

In this study, readers were asked to show their decisions using the two keys on the computer when deciding whether the word pairs they saw on the screen were the same or not. One of the keys is the right tab key and the other is the left tab key. For this reason, word decoding performances of the participants in both verbal and quantitative groups were analyzed with two different GLM-ANOVA on the basis of hand preferences (left, right hand). It was seen that the hand preferences of students in both quantitative and verbal groups did not provide a significant difference in terms of both accuracy and speed of decoding.

\section{Discussion and Conclusion}

Consistent with the dual-route-cascaded model the students decoded the real-words faster than the pseudo-words. We expected that the students from verbal graduate programs read better than the students from quantitative graduate programs. The results suggest that university students from quantitative and verbal programs have similar word decoding strategies. One of the reasons may be that all students pass the university exam, which is a qualifying exam. If the test was applied to all high school graduates, differences could be observed.

It is the first study in Turkey to investigate the word decoding skills of the students from different graduate programs. Examining the students' sentence and text comprehension performance will provide important information about their reading profiles in further research. 